\title{
Dampak Pembelajaran Process Oriented Guided Inquiry Learning Terhadap Pengetahuan Metakognitif Siswa Pada Topik Kesetimbangan Kelarutan
}

\author{
Wiwin Dwi Nurpitasari ${ }^{1}$, Effendy $^{1}$, Sumari $^{1}$ \\ ${ }^{1}$ Pendidikan Kimia-Universitas Negeri Malang
}

\begin{tabular}{l}
\hline \hline INFO ARTIKEL \\
\hline Riwayat Artikel: \\
Diterima: $13-01-2020$ \\
Disetujui: $13-10-2020$ \\
\hline
\end{tabular}

\section{Kata kunci:}

metacognitive knowledge; solubility equilibrium; process oriented guided inquiry learning;

pengetahuan metakognitif; kesetimbangan kelarutan; process oriented guided inquiry learning

\author{
Alamat Korespondensi: \\ Wiwin Dwi Nurpitasari \\ Pendidikan Kimia \\ Universitas Negeri Malang \\ Jalan Semarang 5 Malang \\ E-mail: splash.wiwindn@gmail.com
}

\begin{abstract}
ABSTRAK
Abstract: The aim of this study is to investigate the difference of XI grade science students' metacognitive knowledge as the impact of POGIL and verification learning on solubility equilibrium topic. The study used quasy experiment design. Analysis is done using Mann-Whitney U test at 5\% significance. The result showed that there is difference on students' metacognitive knowledge who are taught by POGIL and verification learning. The students who are taught by POGIL have higer metacognitive knowledge than that of are taught by verification learning.
\end{abstract}

\begin{abstract}
Abstrak: Penelitian ini bertujuan untuk mengetahui perbedaan pengetahuan metakognitif siswa kelas XI IPA sebagai dampak dari pembelajaran POGIL dan verifikasi pada topik kesetimbangan kelarutan. Desain penelitian yang digunakan adalalah quasy experiment. Analisis dilakukan dengan menggunakan uji Mann-Whitney $U$ pada taraf signifikansi $5 \%$. Hasil penelitian menunjukkan terdapat perbedaan pengetahuan metakognitif antara siswa yang dibelajarkan dengan menggunakan pembelajaran POGIL dan verifikasi. Siswa yang dibelajarkan dengan POGIL memiliki pengetahuan metakognitif lebih tinggi dibandingkan siswa yang dibelajarkan dengan pembelajaran verifikasi.
\end{abstract}

Karakteristik pembelajaran topik kesetimbangan kelarutan melibatkan pemahaman konseptual dan perhitungan algoritmik serta mencangkup tiga level representasi kimia, yaitu makroskopik, submikroskopik, dan simbolik (Rahmi, dkk, 2017). Beberapa penelitian terdahulu menunjukkan bahwa sebagian siswa mengalami kesulitan dalam mempelajari topik ini (Raviolo, 2001; Önder \& Geban, 2006; O’Sullivan \& Crouch, 2009; Cam, 2009; Viyandari, 2012; Maharani, 2013). Berdasarkan karakteristiknya, kesulitan yang dialami siswa disebabkan oleh penguasaan konsep-konsep abstrak, seperti molaritas, stoikiometri, senyawa ionik, kesetimbangan kimia, prinsip Le Chatelier, kimia larutan, dan persamaan kimia sebagai prior knowledge harus dimiliki lebih dulu (Raviolo, 2001; Önder \& Geban, 2006; Cam, 2009) serta pembelajaran yang masih menitikberatkan pada perhitungan algoritmik (representasi simbolik) (Raviolo, 2001). Pemahaman konsep-konsep yang bersifat abstrak membutuhkan penggunaan analogi dan model dalam pembelajarannya (Gabel, 1999). Kurangnya analogi dan model menyebabkan siswa kesulitan dalam membangun model mental dari konsep yang dipelajari. Bila model mental yang dibangun siswa tidak sesuai dengan model ilmiah, selanjutnya dapat menyebabkan miskonsepsi. Sementara itu, pembelajaran yang lebih didominasi dengan penggunaan simbol, formula, dan persamaan matematika untuk menjelaskan hubungan antara level makroskopik dan submikroskopik membuat konsep kimia menjadi semakin sulit dipahami (Gabel, 1999). Kendala pemahaman konsep yang lain adalah kesulitan siswa menghubungkan pemahaman dari satu level representasi ke level yang lain (Gabel, 1999; Gilbert \& Treagust, 2009).

Menurut Thomas \& Anderson (2014), untuk membantu siswa mendapatkan pemahaman konsep yang lebih baik dan mengatasi kesulitan dalam menginterrelasikan tiga level representasi adalah dengan melibatkan metakognisi. Metakognisi adalah pengetahuan seseorang tentang proses dan produk kognitifnya (Flavell, 1979) yang selanjutnya dapat digunakan untuk mengontrol proses tersebut (Pitchard, 2013). Metakognisi diperlukan dalam pembelajaran kimia karena merupakan kunci untuk pembelajaran yang lebih dalam dan tahan lama, dibutuhkan untuk menguasai materi, dan dapat mengembangkan kemampuan problem solving (Cooper \& Sandi-Urena, 2009). Menurut Schraw \& Moshman (1995) metakognisi dibagi menjadi dua komponen, yaitu pengetahuan metakognitif dan regulasi metakognitif. Flavell (1979) mendeskripsikan pengetahuan metakognitif sebagai pengetahuan tentang faktor apa saja yang berperan dalam pembelajaran dan capaian kognitif siswa. Siswa dapat memahami, menambah, menghapus, bahkan merevisi pengetahuan metakognitif yang dimiliki (Van Velzen, 2016). 
Regulasi metakognitif merupakan proses yang digunakan untuk mengontrol pikiran pebelajar (Flavell, 1979). Menurut Schraw \& Moshman (1995), pada banyak situasi belajar, regulasi metakognitif terjadi secara otomatis sehingga sulit untuk disampaikan kepada orang lain. Oleh karena itu, penelitian ini hanya akan berfokus pada pengetahuan metakognitif. Pengetahuan metakognitif selanjutnya dibagi menjadi tiga subkomponen, yaitu pengetahuan deklaratif, prosedural, dan kondisional. Pengetahuan deklaratif berkaitan dengan pengetahuan tentang sesuatu. Pengetahuan prosedural berkaitan dengan pengetahuan tentang bagaimana melakukan sesuatu. Sementara itu, pengetahuan kondisional berkaitan dengan pengetahuan tentang kapan dan mengapa sesuatu dilakukan.

Pengetahuan metakognitif berperan dalam membantu siswa mendapatkan pemahaman menyeluruh sesuai karakteristik topik kesetimbangan kelarutan. Penguasaan karakteristik yang pertama membutuhkan pengetahuan prosedural untuk membantu siswa melakukan langkah-langkah sistematis yang diperlukan dalam mengonstruk konsep, melakukan perhitungan, maupun menyelesaikan masalah. Pengetahuan deklaratif terkait materi-materi terdahulu dibutuhkan untuk memudahkan siswa dalam mengonstruk konsep baru. Sementara itu, penguasaan karakteristik kedua membutuhkan pengetahuan kondisional dalam pemilihan informasi, konsep, prinsip, maupun strategi agar siswa dapat menginterelasikan ketiga level representasi untuk menjelaskan fenomena kimia maupun menyelesaikan masalah. Kemampuan siswa dalam menginterelasikan ketiga level representasi dipercaya dapat meningkatkan pemahaman konseptual (Gultepe, 2013). Melihat pentingnya peran pengetahuan metakognitif, kesulitan dalam mempelajari topik kesetimbangan kelarutan juga dapat disebabkan oleh pembelajaran yang tidak mengakomodasi pengembangan pengetahuan metakognitif.

Studi lapangan menunjukkan bahwa saat ini sebagian besar guru sains kelas 8-12 masih menggunakan pendekatan verifikasi dalam pembelajarannya (Montes \& Rockley, 2002). Pembelajaran verifikasi dimulai dengan penjelasan materi oleh guru dilanjutkan dengan pembuktian prinsip dan konsep melalui aktivitas laboratorium (Pavelich \& Abraham, 1979). Pembelajaran jenis ini menyebabkan siswa pasif secara mental, tidak perlu melakukan eksplorasi, dan membatasi kreativitas siswa selama proses pembelajaran (Montes \& Rockley, 2002). Akibatnya, tidak terjadi proses mental yang berarti dalam benak siswa selama pembelajaran (Domin, 1999). Guru dan siswa terfokus pada prosedur dan hasil yang seharusnya didapat dan melupakan kemampuan-kemampuan yang dapat dikembangkan selama kegiatan laboratorium. Berdasarkan penjelasan tersebut, pembelajaran verifikasi dirasa masih kurang mampu mengakomodasi pengembangan pengetahuan metakognitif secara maksimal.

Salah satu pendekatan konstruktivis yang dapat meningkatkan pemahaman konsep dan mengembangkan metakognisi adalah Process Oriented Guided Inquiry Learning (POGIL) (Eaton, 2006; Moog \& Spencer, 2008; Karadan \& Hameed, 2016). POGIL merupakan salah satu pengembangan inkuiri terbimbing yang memacu keterlibatan aktif siswa dalam pembelajaran melalui serangkaian stimulasi intelektual yang disusun secara sistematis. Tahapan dalam pembelajaran POGIL terbagi menjadi lima, yaitu orientasi, eksplorasi, pembentukan konsep, aplikasi, dan penutup. Bagaimana pengetahuan metakognitif dapat dikembangkan pada tiap tahapan POGIL diuraikan pada contoh berikut. Ketika siswa akan belajar konsep efek ion senama terhadap kelarutan $\mathrm{Ca}(\mathrm{OH})_{2}$, pada tahap orientasi pengetahuan deklaratif siswa dilatih. Siswa diingatkan kembali konsep yang sudah dipelajari dengan meminta mereka menuliskan reaksi yang terjadi pada larutan jenuh $\mathrm{Ca}(\mathrm{OH})_{2}$. Pada tahap eksplorasi, disediakan data hasil percobaan titrasi larutan jenuh $\mathrm{Ca}(\mathrm{OH})_{2}$ dalam pelarut air dan pelarut $\mathrm{CaCl}_{2}$. Siswa diberikan serangkaian pertanyaan pembimbing yang menuntun mereka dalam menggunakan segala pengetahuan yang dimiliki untuk menjelaskan perbedaan hasil percobaan. Pada akhir tahap eksplorasi, pertanyaan pembimbing akan menuntun siswa untuk menemukan pola dan membuat kaitan antara pengetahuan yang dimiliki dengan pemahaman yang baru mereka dapat.

Pada tahap ini, siswa akan memahami bahwa ada serangkaian prosedur yang harus dilalui untuk mengonstruk konsep baru. Pengetahuan prosedural siswa akhirnya dapat dikembangkan. Pada tahap eksplorasi, pengetahuan kondisional diperlukan siswa untuk memilih pengetahuan awal mana saja yang dapat digunakan untuk membantu menjelaskan data percobaan. Pengetahuan kondisional juga dilatih ketika siswa, yang terkadang perlu, menggunakan pengetahuan dari konteks berbeda untuk menarik kesimpulan pada tahap pembentukan konsep. Selanjutnya, pada tahap aplikasi pengetahuan deklaratif, prosedural, dan kondisional dilatih secara bersamaan ketika siswa diminta menggunakan konsep baru untuk menyelesaikan masalah. Beberapa penelitian terdahulu menunjukkan kegiatan pembelajaran berbasis inkuiri dapat mengembangkan pengetahuan metakognitif. Kipnis \& Hofstein (2008) melaporkan bahwa kegiatan laboratorium berbasis inkuiri mampu meningkatkan pengetahuan dan kemampuan metakognitif siswa. Hasil penelitian Dedić (2014) menunjukkan bahwa siswa yang berulang kali diberikan tugas berbasis inkuiri mengalami peningkatan pada pengetahuan metakognitif terutama terkait tugas dan strategi. Berdasarkan uraian di atas, POGIL diduga dapat digunakan untuk mengembangkan pengetahuan metakognitif siswa pada topik kesetimbangan kelarutan.

\section{METODE}

Rancangan penelitian yang digunakan adalah eksperimen semu (quasy experiment) posttest only control group design. Populasi penelitian adalah seluruh siswa kelas XI IPA MAN Kota Batu tahun ajaran 2018/2019 yang berjumlah 164 orang dan terdistribusi dalam lima kelas. Identifikasi kemampuan awal siswa dilakukan berdasarkan skor ujian akhir semester I tahun 2018. Hasil identifikasi kemampuan awal siswa ditunjukkan pada tabel 1. 
Tabel 1. Hasil Identifikasi Kemampuan Awal Siswa

\begin{tabular}{|c|c|c|c|c|}
\hline Uji yang dilakukan & Uji yang digunakan & Kriteria uji & Hasil & Kesimpulan \\
\hline Uji normalitas & Kolmogorov-Smirnov & $\begin{array}{l}\text { - Data terdistribusi normal bila } \\
\text { signifikansi >0,05 }\end{array}$ & $\begin{array}{ll}- & \text { XI IPA } 1=0,200 \\
- & \text { XI IPA } 2=0,200 \\
- & \text { XI IPA } 3=0,200 \\
- & \text { XI IPA } 4=0,168 \\
- & \text { XI IPA } 5=0,200\end{array}$ & Data terdistibusi normal \\
\hline Uji homogenitas & Levene's Test & $\begin{array}{l}\text { - Varian data homogen bila } \\
\text { signifikansi }>0,05\end{array}$ & 0,19 & Varian data homogen \\
\hline $\begin{array}{l}\text { Uji kesamaan rata- } \\
\text { rata }\end{array}$ & One way ANOVA & $\begin{array}{l}\text { - Tidak ada perbedaan rata-rata } \\
\text { bila } F_{\text {hitung }}<F_{\text {tabel }} \\
\text { - } F_{\text {tabel }}(\mathrm{dfl}=4 ; \mathrm{df} 2=159 ; \alpha=0,05)=2,43\end{array}$ & 2,165 & $\begin{array}{l}\text { Tidak ada perbedaan } \\
\text { kemampuan awal }\end{array}$ \\
\hline
\end{tabular}

Penentuan sampel dilakukan dengan teknik simple random sampling. Sampel yang diperoleh adalah kelas XI IPA I yang terdiri dari 28 siswa sebagai kelas eksperimen dan kelas XI IPA 2 yang terdiri dari 27 siswa sebagai kelas kontrol Pada penelitian ini, variabel bebas adalah jenis pembelajaran yang digunakan yaitu POGIL dan verifikasi. Variabel terikat adalah pengetahuan metakognitif dan kemampuan problem solving siswa. Variabel kontrol adalah kemampuan awal siswa, materi ajar, guru, interaksi antara kelas eksperimen dan kontrol selama jam pelajaran kimia. Instrumen yang digunakan dalam penelitian ini adalah instrumen perlakuan yang terdiri dari RPP, buku kerja, dan instrumen pengukuran yaitu tes pengetahuan metakognitif yang berupa soal uraian. Validasi instrumen yang dilakukan adalah validasi isi untuk instrumen perlakuan dan pengukuran serta validasi butir soal untuk instrumen pengukuran. Reliabilitas instrumen pengukuran dihitung dengan menggunakan analisis Cronbach alpha. Tes pengetahuan metakognitif yang digunakan terdiri dari tes pengetahuan deklaratif sebanyak enam butir soal, tes pengetahuan prosedural sebanyak tiga butir soal, dan tes pengetahuan kondisional sebanyak empat butir soal. Penskoran tes pengetahuan metakognitif dilakukan dengan mengacu pada rubrik yang dikembangkan oleh Jakabcsin \& Lane (1995). Data yang sudah dikumpulkan selanjutnya dianalisis secara kuantitatif menggunakan analisis inferensial, yaitu uji komparatif.

HASIL

Tabel 2. Skor Tes Pengetahuan Metakognitif Siswa

\begin{tabular}{|c|c|c|c|c|c|c|}
\hline \multirow{2}{*}{ Kelas } & \multicolumn{6}{|c|}{ Skor Tes Pengetahuan Metakognitif } \\
\hline & $\bar{X}$ (total) & $N$ & $S D$ & Jenis Pengetahuan & $\bar{X}$ & SD \\
\hline \multirow{3}{*}{ Eksperimen } & \multirow{3}{*}{23,50} & \multirow{3}{*}{28} & \multirow{3}{*}{5,39} & Deklaratif & 8,25 & 1,48 \\
\hline & & & & Prosedural & 10,21 & 3,89 \\
\hline & & & & Kondisional & 5,00 & 1,49 \\
\hline \multirow{3}{*}{ Kontrol } & \multirow{3}{*}{18,28} & \multirow{3}{*}{27} & \multirow{3}{*}{3,51} & Deklaratif & 7,81 & 2,48 \\
\hline & & & & Prosedural & 5,78 & 1,97 \\
\hline & & & & Kondisional & 4,67 & 1,41 \\
\hline
\end{tabular}

\section{Keterangan:}

$\bar{X} \quad$ : rata-rata skor

$N \quad$ : jumlah siswa

SD : standar deviasi

Skor maksimal tes pengetahuan metakognitif $=45($ deklaratif $=12 ;$ prosedural $=17 ;$ kondisional $=16)$

Berdasarkan tabel 2, tampak bahwa skor rata-rata pengetahuan metakognitif kelas eksperimen lebih tinggi dibanding skor rata-rata kelas verifikasi. Fakta tersebut menunjukkan bahwa pada pembelajaran Kesetimbangan Kelarutan, POGIL menghasilkan pengetahuan metakognitif yang lebih tinggi dibandingkan dengan pembelajaran verifikasi. Untuk membuktikan signifikansi dari fakta tersebut, dilakukan uji secara statistik. Sebelum melakukan uji hipotesis, dilakukan uji prasyarat analisis, yaitu uji normalitas untuk mengetahui kenormalan distribusi data dan uji homogenitas untuk mengetahui kehomogenan varian data. Apabila kedua uji prasyarat terpenuhi, uji hipotesis dilakukan menggunakan analisis parametrik. Apabila salah satu atau kedua uji prasyarat tidak terpenuhi, uji hipotesis dilakukan secara nonparametrik. Hasil uji prasayat analisis dan uji hipotesis tes pengetahuan metakognitif siswa diberikan pada tabel 3 . 
Tabel 3. Hasil Uji Prasyarat Analisis dan Uji Hipotesis Tes Pengetahuan Metakognitif Siswa

\begin{tabular}{|c|c|c|c|c|c|}
\hline Uji yang dilakukan & $\alpha$ & Uji yang digunakan & Kriteria uji & Hasil & Kesimpulan \\
\hline Uji normalitas & 0,05 & Kolmogorov-Smirnov & $\begin{array}{l}\text { - Data terdistribusi } \\
\text { normal bila } \\
\text { signifikansi }>0,05\end{array}$ & $\begin{array}{l}\text { - } \text { Kelas eksperimen = } \\
0,200 \\
\text { - } \text { Kelas kontrol = 0,200 }\end{array}$ & Data terdistibusi normal \\
\hline Uji homogenitas & 0,05 & Levene's Test & $\begin{array}{l}\text { - Varian data homogen } \\
\text { bila } \\
\text { signifikansi }>0,05\end{array}$ & 0,007 & $\begin{array}{l}\text { Varian data tidak } \\
\text { homogen }\end{array}$ \\
\hline Uji hipotesis & 0,05 & Mann-Whitney $U$ & 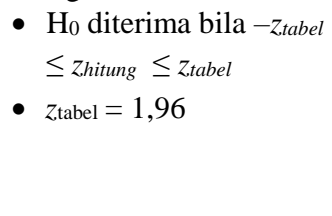 & $-3,62$ & $\begin{array}{l}\mathrm{H}_{0} \text { ditolak. Ada } \\
\text { perbedaan pengetahuan } \\
\text { metakognitif antara } \\
\text { siswa yang dibelajarkan } \\
\text { dengan POGIL dan } \\
\text { verifikasi. }\end{array}$ \\
\hline
\end{tabular}

\section{PEMBAHASAN}

Hasil analisis data menunjukkan bahwa pembelajaran POGIL memberikan dampak yang lebih signifikan terhadap pengetahuan metakognitif siswa. Berdasarkan tabel 2, rata-rata tes pengetahuan metakognitif siswa yang dibelajarkan dengan POGIL lebih tinggi 5,22 poin dibanding kelas verifikasi dengan skor tes pengetahuan metakognitif maksimal 45 poin. Hal ini disebabkan oleh perbedaan aktivitas siswa pada pembelajaran POGIL dan verifikasi. Pada pembelajaran POGIL, siswa diberikan berbagai scaffolding yang merupakan stimulasi intelektual untuk memacu siswa terlibat aktif, baik secara fisik maupun mental, dalam pembelajaran.

Hasil penelitian ini paralel dengan sejumlah penelitian terdahulu. Kipnis \& Hofstein (2008) melaporkan bahwa kegiatan laboratorium berbasis inkuiri mampu meningkatkan pengetahuan dan kemampuan metakognitif siswa. Hasil penelitian Dedić (2014) menunjukkan bahwa siswa yang berulang kali diberikan tugas berbasis inkuiri mengalami peningkatan pada pengetahuan metakognitif terutama terkait tugas dan strategi. Siswa yang dibelajarkan dengan POGIL juga menunjukkan pengetahuan metakognitif yang lebih tinggi dibanding siswa yang dibelajarkan dengan verifikasi pada materi asam basa (Ardhana, 2017). Mereka dapat memberikan pola jawaban tes pengetahuan deklaratif, prosedural, dan kondisional yang lebih baik dibanding siswa yang dibelajarkan dengan verifikasi. Pembahasan lebih lanjut terkait pengetahuan deklaratif, prosedural, dan kondisional pada pembelajaran POGIL dan verifikasi diuraikan sebagai berikut.

\section{Pengetahuan Deklaratif}

Berdasarkan tabel 2, rata-rata tes pengetahuan deklaratif siswa yang dibelajarkan dengan POGIL lebih tinggi 0,44 poin dibanding kelas verifikasi dengan skor tes pengetahuan deklaratif maksimal 12 poin. Hal ini dapat dijelaskan sebagai berikut. POGIL merupakan pembelajaran berbasis penemuan. Pada pembelajaran POGIL, siswa lebih aktif mengonstruk pengetahuan baru melalui observasi, analisis, diskusi, menentukan kaitan, dan aktivitas kognitif lainnya dalam kelompok kecil. Siswa yang terlibat aktif dalam pembelajaran, memiliki pengalaman belajar yang lebih banyak dan cenderung lebih membekas dalam pikiran. Hasilnya, pengetahuan yang didapat menjadi lebih bermakna dan memiliki retensi yang lebih baik. Penjelasan ini sejalan dengan pernyataan Barke, dkk (2012) bahwa semakin aktif siswa dalam perolehan pengetahuan semakin lama retensi pengetahuan tersebut dalam benak siswa. Hal ini selanjutnya akan memudahkan siswa ketika suatu saat perlu memanggil kembali pengetahuan yang dimiliki. Mereka mampu mendeklarasikan konten pengetahuan dalam suatu kesatuan yang lengkap dan runtut. Kemampuan memanggil kembali pengetahuan dan mendeklarasikannya dalam kesatuan yang lengkap merupakan indikator pengetahuan metakognitif, yaitu pengetahuan deklaratif. Dengan demikian, pengetahuan deklaratif siswa dapat berkembang lebih baik.

Pada pembelajaran verifikasi, pengalaman belajar didapat melalui kegiatan mendengarkan, mencatat, dan membuktikan konsep. Pengalaman belajar seperti ini kurang melibatkan siswa secara aktif, baik fisik maupun mental. Semua konsep, definisi, rumus perhitungan, bahkan prosedur pembuktian telah disediakan oleh guru. Siswa kurang diberi kesempatan untuk berpikir dalam kegiatan yang eksploratif. Sesuai dengan apa yang dinyatakan Barke, dkk (2012), hanya sekitar 50\%, atau bahkan kurang, pengetahuan yang bisa diperoleh siswa melalui pengalaman belajar yang disediakan dalam pembelajaran verifikasi. Akibatnya, pengetahuan yang didapat menjadi kurang bermakna dan hanya tersimpan dalam memori untuk jangka waktu yang pendek. Ketika suatu saat siswa diminta memanggil kembali pengetahuannya, mereka tidak akan mampu mendeklarasikannya dalam kesatuan yang lengkap. Pengetahuan deklaratif siswa akhirnya menjadi kurang berkembang.

\section{Pengetahuan Prosedural}

Berdasarkan tabel 2, rata-rata tes pengetahuan prosedural siswa yang dibelajarkan dengan POGIL lebih tinggi 4,43 poin dibanding kelas verifikasi dengan skor tes pengetahuan prosedural maksimal 17 poin. Hal ini dapat dijelaskan sebagai berikut. Pada pembelajaran POGIL, siswa diberikan stimulasi intelektual berupa pertanyaan-pertanyaan penuntun yang disusun secara runtut dan sistematis di tahap eksplorasi. Sementara pada tahap pembentukan konsep, siswa distimulasi untuk 
menemukan informasi penting dan menarik ide utama, hasil dari tahap eksplorasi, yang selanjutnya diolah menjadi konsep baru. Mereka dituntut melakukan analisis, menggali informasi, dan menentukan pola dalam data untuk mendapatkan konsep baru. Pada subtopik yang berkaitan dengan hitungan algoritmik, seperti meramalkan terbentuknya endapan, siswa juga tidak begitu saja diberikan rumus jadi. Siswa dituntun untuk memahami asal rumusan tersebut. Ketika siswa diberikan soal yang berkaitan dengan subtopik tersebut, baik secara langsung maupun tidak, mereka dapat menyelesaikannya secara runtut dan sistematis.

Siswa yang dibiasakan belajar melalui tahapan POGIL akan memahami bahwa ada serangkaian langkah prosedural yang perlu dilalui dalam mengonstruk konsep atau menyelesaikan suatu masalah. Dengan demikian, pengetahuan prosedural siswa dapat berkembang lebih baik. Penjelasan ini sejalan dengan pernyataan Kipnis \& Hofstein (2008) bahwa proses inkuiri dapat digunakan untuk melatih pengetahuan prosedural siswa melalui pertanyaan-pertanyaan inkuiri yang diberikan pada tahap eksplorasi dan kesimpulan yang harus didapatkan pada tahap pembentukan konsep.

Pada pembelajaran verifikasi, siswa kurang memperoleh stimulasi intelektual. Pembelajaran diawali dengan pemberian konsep baru oleh guru dan dilanjutkan dengan pembuktian melalui praktikum atau data praktikum yang sudah ada. Prosedur praktikum telah disediakan guru. Pada akhirnya, siswa hanya fokus pada hasil praktikum dan konsep yang mereka miliki. Mereka akan berusaha mencocokkan keduanya dan tidak mentolerir perbedaan. Stimulasi intelektual untuk melatih kemampuan prosedural yang dapat disisipkan dalam prosedur praktikum kurang mendapat perhatian, baik dari guru maupun siswa. Akibatnya, kemampuan prosedural siswa tidak dapat berkembang secara signifikan. Penjelasan ini paralel dengan pernyataan Montes \& Rockley (2002) bahwa praktikum pada pembelajaran verifikasi lebih fokus pada hasil yang telah ditentukan di awal, membatasi eksplorasi siswa, dan kurang mampu membuat siswa memikirkan lebih dalam prosedur yang dilakukan. Pada subtopik yang melibatkan perhitungan algoritmik, siswa diberikan rumus jadi tanpa mengetahui asal rumusan tersebut. Akibatnya, siswa akan menghafalkannya dan hanya mampu mengerjakan soal yang berkaitan langsung dengan rumus. Apabila kondisi soal diubah, siswa tidak akan mampu melakukan langkah-langkah prosedural tambahan untuk menyelesaikannya.

\section{Pengetahuan Kondisional}

Berdasarkan tabel 2, rata-rata tes pengetahuan kondisional siswa yang dibelajarkan dengan POGIL lebih tinggi 0,33 poin dibanding kelas verifikasi dengan skor tes pengetahuan kondisional maksimal 16 poin. Hal ini dapat dijelaskan sebagai berikut. Pada pembelajaran POGIL, siswa diingatkan kembali prior knowledge yang diperlukan untuk mengonstruk pengetahuan baru ditahap orientasi dan atau eksplorasi. Proses ini dilakukan dengan memberikan pertanyaan-pertanyaan yang memacu siswa untuk mengingat konsep yang sudah dipelajari dan menemukan kaitannya dengan konsep yang akan dipelajari. Pada tahap ini, siswa menyadari bahwa konsep-konsep yang telah dipelajari dapat dijadikan pondasi untuk mempelajari konsep yang baru. Ketika pembelajaran usai, siswa mampu menata pengetahuan baru dan lamanya dalam satu kesatuan yang kokoh dan terstruktur. Selanjutnya, siswa diberikan stimulan berupa soal pada tahap aplikasi. Pada tahap tersebut siswa dilatih untuk memahami mengapa suatu konsep digunakan untuk menyelesaikan masalah tertentu. Siswa yang dibelajarkan dengan POGIL mampu menentukan konsep apa saja yang diperlukan untuk menyelesaikan soal. Mereka juga mampu memberikan alasan dan kaitan yang logis bagaimana konsep-konsep tersebut dapat menjawab soal. Kegiatan mengakses pengetahuan yang paling sesuai untuk kondisi tertentu, baik yang baru dipelajari atau yang telah lalu, merupakan indikator keterlibatan pengetahuan metakognitif, yaitu pengetahuan kondisional. Pengetahuan kondisional siswa akhirnya dapat dilatih dan dikembangkan. Penjelasan ini paralel dengan pernyataan Kipnis \& Hofstein (2008) bahwa aktivitas inkuiri pada pembelajaran POGIL dapat melatih pengetahuan kondisional ketika siswa menggunakan pengetahuan dari konteks berbeda untuk menarik kesimpulan.

Pada pembelajaran verifikasi, perolehan konsep baru tidak membutuhkan waktu lama karena informasi ditransfer langsung dari guru ke siswa. Seperti halnya dalam pembelajaran POGIL, siswa juga diingatkan kembali prior knowledge yang diperlukan pada pendahuluan pembelajaran. Akan tetapi pada tahap selanjutnya, konsep baru dan kaitannya dengan prior knowledge siswa dijelaskan langsung oleh guru. Hal ini menyebabkan siswa secara mental kurang aktif dalam membuat koneksi antara pengetahuan yang sudah dimiliki dengan konsep yang baru dipelajari. Siswa menjadi kurang mampu menyusun pengetahuan-pengetahuan yang ia miliki menjadi suatu kesatuan yang kokoh dan terstruktur. Bahkan, apabila guru kurang memberikan penekanan maupun pendalaman pada kaitan antara pengetahuan lama dan konsep baru, konsep tersebut akan menjadi pengetahuan baru yang terpisah dengan pengetahuan lainnya dalam benak siswa. Penjelasan ini paralel dengan pernyataan Domin (1999) bahwa pembelajaran verifikasi tidak mengakomodasi pemrosesan informasi secara mendalam, yaitu pengintegrasian antara pengalaman baru dengan prior knowledge siswa. Akibatnya, ketika menjawab soal, siswa kurang mampu memberikan jawaban yang mendalam. Siswa kurang mampu memadukan berbagai konsep yang sesuai dan menjelaskan keterkaitannya untuk memberikan alasan logis yang dapat menjawab soal. Pengetahuan kondisional siswa akhirnya menjadi kurang berkembang.

\section{SIMPULAN}

Berdasarkan hasil analisis data dan pembahasan dapat disimpulkan bahwa terdapat perbedaan pengetahuan metakognitif siswa yang dibelajarkan menggunakan POGIL dan yang dibelajarkan menggunakan verifikasi pada topik Kesetimbangan Kelarutan. Siswa yang dibelajarkan dengan POGIL memiliki pengetahuan metakognitif yang lebih tinggi dibanding siswa yang dibelajarkan dengan verifikasi. 
Berdasarkan hasil penelitian, dapat diberikan beberapa saran, yaitu (1) pembelajaran topik kesetimbangan kelarutan seharusnya dilakukan dengan menggunakan pendekatan yang dapat memicu keterlibatan aktivitas kognitif siswa. Pembelajaran inkuiri tipe POGIL dapat menjadi alternatif pilihan untuk mewujudkan hal tersebut; (2) pembelajaran yang melibatkan pengetahuan metakognitif layak dipromosikan agar siswa terlatih untuk berpikir secara terkontrol dan sistematis; (3) para peneliti selanjutnya dapat melengkapi hasil penelitian ini dengan memfokuskan penelitian untuk memperoleh data kualitatif terkait pengetahuan metakognitif siswa.

\section{DAFTAR RUJUKAN}

Barke, H. D., Harsch, G., \& Schmid, S. (2012). Essentials of Chemical Education. Berlin: Springer.

Cam, A. (2009). Effectiveness of Case-Based Learning Instruction on Students' Understanding of Solubiliti Equilibrium Concepts. Unpublised Doctoral Thesis. Turkey: Middle East Technical University.

Cooper, M. M., \& Sandi-Urena, S. (2009). Design and Validation of an Instrument to Assess Metacognitive Skillfulness in Chemistry Problem Solving. Journal of Chemical Education, 86(2), 240. https://doi.org/10.1021/ed086p240.

Dedić, Z. R. (2014). Metacognitive Knowledge in Relation to Inquiry Skills and Knowledge Acquisition Within a ComputerSupported Inquiry Learning Environment. Psihologijske Teme, 23(1), 115-141.

Domin, D. S. (1999). A Review of Laboratory Instruction Styles, 76(4), 543-547.

Eaton, L. (2006). The Effect of Process Oriented Guided Inquiry Learning on Student Achievement in a One Semester General, Organic, and Biochemistry. Unpublished Magister Thesis. Charleston: St. John Fisher College.

Flavell, J. H. (1979). Metacognition and Cognitive Monitoring: A New Area of Cognitive-Developmental Inquiry. American Psychologist, 34(10), 906-911. https://doi.org/10.1037/0003-066X.34.10.906.

Gabel, D. (1999). Improving Teaching and Learning through Chemistry Education Research: A Look to the Future. Journal of Chemical Education, 76(4), 548, https://doi.org/10.1021/ed076p548.

Gilbert, J. K. \& Treagust, D. F. (2009). Towards a Coherent Model for Macro, Submicro, and Symbolic Representation in Chemistry Education. In Multiple Representation in Chemistry Education (pp. 333-350). Springer Netherlands.

Gultepe, N. (2013). Exploring Effects of High School Students' Mathematical Processing Skills and Conceptual Understanding of Chemical Concepts on Algorithmic Problem Solving, 38(10), 106-122.

Karadan, M., \& Hameed A. (2016). Exploring the Features of Metacognition and Achievement Goals in Process Oriented Guided Inquiry Learning Instruction (POGIL). International Journal of Education and Phychological Research, 5(3), 3943.

Kipnis, M., \& Hofstein, A. (2008). The Inquiry Laboratory as a Source for Development of Metacognitive Skills. International Journal of Science and Mathematics Education, 6(3), 601-627. https://doi.org/10.1007/s10763-007-9066-y.

Maharani, T. Y. (2013). Menggali Pemahaman Siswa SMA pada Konsep Kelarutan dan Hasil Kali Kelarutan dengan Menggunakan Tes Diagnostik Two-Tier. Skripsi tidak diterbitkan. Universitas Negeri Malang, Malang.

Montes, L. D., \& Rockley, M. G. (2002). Teacher Perceptions in the Selection of Experiments. Journal of Chemical Education, 79(2), 244-247.

Moog, R. S. \& Spencer, J. N. (2008). POGIL: An Overview. The POGIL Project. Lancaster: Department of Chemistry.

O’Sullivan, D.W., \& Crouch, C. C. (2009). Illustrating the Concept of Sparingly Soluble Salts Using Various Copper Compounds. A Classroom Demonstration. Journal of Chemical Education, 86(2), 202-205. https://doi.org/10.1021/ ed086p202.

Önder, I. \& Geban, O. (2006). The Effect of Conceptual Change Approach on Students' Understanding of Solubility Equilibrium Concept. Journal of Education, 30 (2006), 166-173.

Pavelich, M. J., \& Abraham, M. R. (1979). An Inquiry Format Laboratory Program for General Chemistry. Journal of Chemical Education, 56(2), 100. https://doi.org/10.1021/ed056p100.

Pitchard, T. (2007). Ways of Learning: Learning Theories and Learning Styles in the Classroom. New York: Routledge.

Rahmi, C., Katmiati, S., Wiji, \& Mulyani, S. (2017). Students' Mental Models on The Solubility And Solubility Product Concept. AIP Conference Proceedings, 1848. https://doi.org/10.1063/1.4983933.

Raviolo, A. (2001). Assessing Students' Conceptual Understanding of Solubility Equilibrium. Journal of Chemical Education, 78(5), 629. https://doi.org/ 10.1021/ed078p629.

Schraw, G., \& Moshman, D. (1995). Metacognitive Theories Metacognitive Theories. Educational Psychology Review, 7(4), 351-371. https:// doi.org/10.1007/BF02212307.

Thomas, G. P., \& Anderson, D. (2014). Changing the Metacognitive Orientation of a Classroom Environment to Enhance Students' Metacognition Regarding Chemistry Learning. Learning Environments Research, 17(1), $139-155$. https://doi.org/10.1007/s10984-013-9153-7.

Viyandari, A., Priatmoko, S., \& Latifah. (2012). Analisis Miskonsepsi Siswa terhadap Materi Kelarutan dan Hasil Kali Kelarutan $\left(K_{s p}\right)$ dengan Menggunakan Two-Tier Diagnostic Instrument. Jurnal Inovasi Pendidikan Kimia, 6(1), 852-861.

Van Velzen, J. (2015). Metacognitive Learning: Advancing Learning by Developing General Knowledge of The Learning Process. Metacognitive Learning: Advancing Learning by Developing General Knowledge of the Learning Process, 1162. https://doi.org/10.1007/978-3-319-24433-4. 